\title{
Service reliability assessment using failure mode and effect analysis (FMEA): survey and opportunity roadmap
}

\author{
Agung Sutrisno ${ }^{1}$, Tzong-Ru (Jiun-Shen) Lee ${ }^{2 *}$ \\ ${ }^{1}$ Department of Mechanical Engineering, Sam Ratulangi University, Manado, INDONESIA, \\ ${ }^{2}$ Department of Marketing Management, National Chung Hsing University, TAIWAN, \\ E-mails: (Agung Sutrisno, a6un6sutrisno@yahoo.com); *Corresponding Author - Tzong-Ru (Jiun-Shen) Lee, trlee@dragon.nchu.edu.tw
}

\begin{abstract}
Despite Failure Mode and Effect Analysis (FMEA) being a strategic technique for creation of error free service operation, detailed survey study and development of opportunity roadmap for FMEA application in service operation is limited in literature. We presented a preliminary literature survey between 1994 and 2010 that covers 20 journals from 8 different literature databases. The result of our preliminary survey indicated that majority of previous service FMEA studies focused on profit and supply chain-oriented service business practices. New service FMEA research opportunities relating to enhancement in Risk Priority Number (RPN), reprioritization, versatility of its application in service supply chain framework and non-profit service sector as well as combination with other quality control tools are proposed for further investigations.
\end{abstract}

Keywords: FMEA application in service operation; Risk Priority Number (RPN) reprioritization; Service supply chain; Nonprofit service sectors; Quality control tools

\section{Introduction}

As a sector that contribute to more than 50\% of Gross Domestic Product (GDP) in global economy, the importance of service sector will grow in future (Gecky et al., 2010). Bullinger et al. (2003) stated that in the past decade, the marketing science is more dominating to the development of service as a discipline compare to the contribution by the advancement of techniques from product design and manufacturing discipline. Motivated by above situation, enhancing design tool for error free service operation is necessary. Reliable service as manifested by error free service operation is important subject to dig, since unreliable service operation is becoming the source of customers' dissatisfaction (Yang et al. 2003; Fowdar, 2008; Hong et al. 2010) and driver of unexpected service operation cost. In addition, due to the uniqueness of service characteristics - its intangibility, heterogeneity, inseparability between service provider and consumer, and interrelated relationship among man, machine, and systems makes accessing service reliability has its own challenges (Hashim, 1984). Previous studies that aimed to propose new ideas for future service as a discipline (Menor et al. 2002; Chase and Apte, 2007; Torney et al. 2009 and Ostrom et al. 2010) emphasised the importance of modifying or enhancing reliability assessment tool in product design in service operation. In addition, previous literature that discusses on the progress of reliability assessment issues with FMEA is still focusing in product design and manufacturing (Bouti and Kadi, 1994, Yadav et al. 2008 and Bhamare et al. 2007). Motivated by the gap, we presented a preliminary survey to the state of the art of FMEA studies in literature during the specified time span and propose new research opportunities with focus to service sectors. The term "service FMEA" in this paper is related to the application of FMEA in service operation.

The remainder of the paper is organized as follows: In section 2, we presented the survey methodology used in this research paper. In section 3, we mapped the classifications of previous FMEA studies based on specific criteria. In Section 4, detailed the observable gaps in previous service FMEA studies and new research challenges are presented. Section 5 is related to conclusions and suggestions to extend our initial survey. 


\section{Research Methodology}

Naturally, the service FMEA literature is dispersed to various forms and application settings in the form of periodicals, books, conference proceedings, booklets and so on. To deal with our objective, we used systematic search through literature databases. The FMEA related literature databases spanning from 1994-2010 are chosen. The periodical is preferable among other types of literature since it is perceived as the highest source of research level up-to-date and contains specific issue of interest (Nord and Nord, 1995 in Ngai et al. 2009). The publications such as Emerald, Springer, Ebscohost, Inderscience, Informaworld, Hindawi, Sage, IEExplore, Ingenta, Sciencedirect, and Directory of Open Access Journal (DOAJ) are chosen as the literature databases. Meanwhile, the choice of periodicals to match with the objective of this study is based on factors such as the journals maturity (the length of publication), the impact factor, and scope of the journal. Then, we classify the literature found during the search based on the specific criteria that limited to: FMEA automation, enhancement of FMEA methodology in modelling failure phenomenon, combination of FMEA with other quality tools, FMEA modification, and its versatility in various application settings. We excluded the articles that are written with language other than English. The keywords used in the search are "FMEA", and "FMECA". The finding of the literature search is then reported in a tabular format as shown in Table 1.

\section{Results of Preliminary FMEA Literature Survey}

Referring to the specific criteria as determined earlier, the classification of FMEA literature found in our study is shown as above. Based on the result from our initial survey, many studies have promoted to apply FMEA in various service sectors. Nevertheless, in our point of view; there are still some unobserved spots that warrant for further studies as below:

1. Majority of previous service FMEA studies are still dedicated for profit-oriented service. Although possessing significant amount of financial value and improved quality of societal life, the application of FMEA to other non-profit service sectors such as humanitarian (voluntary) service and governmental (public) service are escaped from previous researchers' attention. Refer to Johnston (2005) and Redman et al. (1995) for details of justification to researches in nonprofit service sectors.

2. The basis to estimate the RPN is based on a 1-10 scale in previous FMEA literature is less scientific that makes the RPN resulted from such estimation prone to lower accuracy and vary among FMEA practitioners in various industries.

3. Previous service FMEA studies are based on assumption that service customers are behaving in good manners during service delivery; although in daily service delivery and customers can also abuse or do sabotage to service provider(s) and or to other customer(s).

4. Although competing through supply chain is becoming the paradigm for nowadays business, previous service FMEA studies are still dedicated to single company practice and overlook on implementing FMEA in supply chain framework.

In addition, considering bi-directionality of customer in service, the change of business paradigm from single company into collaborative business orientation in supply chain framework, the growing concern to sustainability issues, and transition from pure manufacturing business into product-service business scope; there are surely some opportunities in future service FMEA researches. Refer Sampson (2000), Foster (2008), Xu and Wang (2009), and Kim et al. (2010) as basis to get deep insight on service FMEA researches. However, due to the vast scope of service FMEA as subject for further study, we only presented new research opportunities that limited to some areas such as: improvement in estimating the RPN, modification of FMEA method in service operation, and expansion of FMEA study in various service areas.

Table 1. Classification of FMEA References

\begin{tabular}{|l|l|l|}
\hline \multicolumn{1}{|c|}{ FMEA Scope } & \multicolumn{1}{|c|}{ Tool/ Content/Topic } & \multicolumn{1}{c|}{ References } \\
\hline $\begin{array}{l}\text { Combination } \\
\text { with } \\
\text { Other Quality } \\
\text { Tools }\end{array}$ & $\begin{array}{l}\text { FMEA-Quality Function } \\
\text { Deployment (QFD) }\end{array}$ & $\begin{array}{l}\text { Bosch and Golzalves (2005), Tan (2003), Annamalai } \text { et } \\
\text { al.,(2006), Gin } \text { et al., (1998), Pujawan and Geraldin (2009), } \\
\text { Braglia and Frosolini (2007), Al-Mashari } \text { et al., (2005) } \\
\text { Bosch and Enriquez (2005), Chen and Ko (2009), Tanik } \\
\text { (2010), Hassan et al., (2010) }\end{array}$ \\
\cline { 2 - 3 } & FMEA-Fault Tree Analysis (FTA) & Arcidiacono ( 2004) \\
\cline { 2 - 3 } & $\begin{array}{l}\text { FMEA-QFD-Statistical Process } \\
\text { Control-Design Of Experiments }\end{array}$ & He et al., (2002) \\
\cline { 2 - 3 } & FMEA-Statistical Process Control & Teng and Ho (1996) \\
\cline { 2 - 3 } & $\begin{array}{l}\text { FMEA-Hazard Analysis Critical } \\
\text { Control Point (HACCP) }\end{array}$ & $\begin{array}{l}\text { Scipioni (2002), Bertolini } \text { et al., (2006), Varzakas } \text { et al., } \\
\text { (2007), Arvanitoyannis } \text { et al., (2009) }\end{array}$ \\
\hline
\end{tabular}


Table 1 (cont'd). Classification of FMEA References

\begin{tabular}{|c|c|c|}
\hline FMEA Scope & Tool/ Content/Topic & References \\
\hline \multirow{6}{*}{$\begin{array}{l}\text { Combination } \\
\text { with } \\
\text { Other Quality } \\
\text { Tools }\end{array}$} & FMEA-Kano Method & Shahin (2004) \\
\hline & FMEA-Project Management & Santos and Cabral (2008) \\
\hline & FMEA-TRIZ Method & Bariani et al., (2004) \\
\hline & $\begin{array}{l}\text { FMEA-HAZOP (Hazard and } \\
\text { Operability Study) }\end{array}$ & Ilangkumar and Thamizmani (2010) \\
\hline & FMEA-Service Blue Printing & Chuang (2007) \\
\hline & FMEA-Petri Nets & Bertolini et al., (2006) \\
\hline \multirow[t]{16}{*}{$\begin{array}{l}\text { Reprioritization } \\
\text { of the Risk } \\
\text { Priority Number } \\
\text { (RPN) }\end{array}$} & & \\
\hline & Fuzzy Logic & $\begin{array}{l}\text { Pelaez and Bowles(1995), Dong (2009), Puente et al., } \\
\text { (2002), Xu et al., (2002), Sharma et al., (2005), Sharma } \\
\text { and Sharma (2010), Braglia et al., (2003), Kumar and } \\
\text { Chaturvedhy (2011), Aidin and Ozkan (2008), Tan and } \\
\text { Mey (2005), Sharma et al., (2008), Zafiropoulos and } \\
\text { Dyalinas (2000) }\end{array}$ \\
\hline & Cost basis & $\begin{array}{l}\text { Ben Daya and Raouf (1996), Ahsen(2008), Carmignani } \\
\text { (2009), Rhee and Ishii (2003), Jeegadeshan et al., (2007), } \\
\text { Dong (2007), Kmenta and Ishii (2004) }\end{array}$ \\
\hline & $\begin{array}{l}\text { Analytical Hierarchy Priority } \\
\text { (AHP) }\end{array}$ & Braglia (2000), Ouedraogo et al., (2010) \\
\hline & $\begin{array}{l}\text { Multi- Expert Multi Criteria } \\
\text { Decision Making }\end{array}$ & Franceschini and Galleto (2001) \\
\hline & Graph Theory & Gandhi and Agrawal (2002) \\
\hline & $\begin{array}{l}\text { DEMATEL } \\
\text { (Decision-Making Trial and } \\
\text { Evaluation Laboratory) }\end{array}$ & Hosseini et al., (2006), Chang and Cheng (2011) \\
\hline & Poisson Distribution & Senol (2007) \\
\hline & Taguchi Loss Function & Karuppuswamy et al., (2006) \\
\hline & Grey Theory & $\begin{array}{l}\text { Chang et al., (1999), Sharma et al., (2007), Pilay and Wang } \\
\text { (2003) }\end{array}$ \\
\hline & Error Commonality Index & Chao and Ishii (2003) \\
\hline & $\begin{array}{l}\text { TOPSIS } \\
\text { (Technique for Order Preference } \\
\text { by Similarity to Ideal Solution) }\end{array}$ & Sachdeva et al., (2009), Braglia et al., (2003) \\
\hline & Group Oriented Decision Making & Jenap and Dhillon (2005) \\
\hline & Izonote Concept & Gwiazda (2007) \\
\hline & Anova (Analysis of Variance) & Karupussami and Narayanagounder (2009) \\
\hline & Data Envelopment Analysis (DEA) & $\begin{array}{l}\text { Chang and Kuo (2009), Garcia et al., (2005), Chin et al., } \\
\text { (2009) }\end{array}$ \\
\hline
\end{tabular}


Table 1 (cont'd). Classification of FMEA References

\begin{tabular}{|c|c|c|}
\hline FMEA Scope & Tool/ Content/Topic & References \\
\hline \multirow[t]{11}{*}{$\begin{array}{l}\text { Application of } \\
\text { FMEA in } \\
\text { Various } \\
\text { Industrial } \\
\text { Settings } \\
\end{array}$} & & \\
\hline & Mechanical Product Design & $\begin{array}{l}\text { Miguel et al., (2005), Bahmed et al., (2006), Korayem and } \\
\text { Iravani (2008) }\end{array}$ \\
\hline & Food Manufacturing & Scipioni et al., (2002), Bertolini et al., (2006) \\
\hline & Software Development & Rebelo and Goyal (2010), Dilibabu and Krisnaiah (2006) \\
\hline & Building Industry & Layzell and Ledbetter (1998) \\
\hline & Aviation Safety Management & Lee ( 2005) \\
\hline & $\begin{array}{l}\text { Automotive and Shipbuilding } \\
\text { Industry }\end{array}$ & $\begin{array}{l}\text { Albuquerque et al., (2009), Buksa et al., (2010), Estorilo } \\
\text { and Posso (2010) }\end{array}$ \\
\hline & Wastage Treatment & Yeh and Hsieh (2007) \\
\hline & Drug Research \& Development & Inoue and Yamada (2010) \\
\hline & Spare Part Management & Tsakatitas et al., (2007), Braglia et al.,(2005) \\
\hline & Civil Construction Project & Wong et al., (2006) \\
\hline \multirow[t]{12}{*}{$\begin{array}{l}\text { Application of } \\
\text { FMEA in } \\
\text { Various } \\
\text { Industrial } \\
\text { Settings } \\
\end{array}$} & & \\
\hline & Outer Space Program & Satish et al., (2009) \\
\hline & $\begin{array}{l}\text { ERP (Enterprise Resource } \\
\text { Planning) Implementation }\end{array}$ & Yang et al., (2006) \\
\hline & Working Safety Assessment & $\begin{array}{l}\text { Fera and Macchiaroli (2009), Suhendra and Compart } \\
\text { (2007), Thivel et al.,(2008) }\end{array}$ \\
\hline & Goods Quarantine & Dai et al.,(2008) \\
\hline & $\begin{array}{l}\text { Semiconductor and Metal } \\
\text { Manufacturing }\end{array}$ & $\begin{array}{l}\text { Byrne and Sheahan (2007), Deng et al., (2007), Mili et al., } \\
\text { (2009) }\end{array}$ \\
\hline & Entertainment Security & Berkeley (1998), \\
\hline & Healthcare & $\begin{array}{l}\text { Jeong et al. (2007), Ookalkar et al., (2009), Chiozza and } \\
\text { Pozenti (2009), Mummolo et al., (2010), Chang et. al } \\
\text { (2010), Geum et al., (2010), Aksezer (2010), De Giorgi et } \\
\text { al., (2010), Attike et al., (2010) }\end{array}$ \\
\hline & Maintenance & $\begin{array}{l}\text { Bertolini et al., (2006), Pujadas and Chen (1996), Elharam } \\
\text { and Horner (2002), Al-Mishari and Sulaiman (2008) }\end{array}$ \\
\hline & Education & Shintavalai and Mamengkol (2008), \\
\hline & Travel & Shahin (2004) \\
\hline & Electronic Commerce & Linton (2003) \\
\hline
\end{tabular}


Table 1 (cont'd). Classification of FMEA References

\begin{tabular}{|c|c|c|}
\hline FMEA Scope & Tool/ Content/Topic & References \\
\hline \multicolumn{3}{|l|}{$\begin{array}{l}\text { Application of } \\
\text { FMEA in } \\
\text { Various } \\
\text { Industrial } \\
\text { Settings } \\
\end{array}$} \\
\hline & Residential Service Provision & Browman et al., (2010) \\
\hline & Transportation Service & Jeegadeshan et al., (2007) \\
\hline & Consumer Good Trading & Chuang (2007), Chuang (2010) \\
\hline & Sales Service & Qiang (2009) \\
\hline & Culinary & Ozilgen (2010) \\
\hline \multicolumn{3}{|l|}{$\begin{array}{l}\text { Application of } \\
\text { FMEA in Supply } \\
\text { Chain } \\
\text { Framework }\end{array}$} \\
\hline & Pharmaceutical Logistics & Kumar et al., (2009) \\
\hline & Aerospace Product Manufacturing & Sinha et al., (2004) \\
\hline & $\begin{array}{l}\text { Automotive product design and } \\
\text { Manufacturing }\end{array}$ & Leung et al., (2005), Teng et al.,(2006) \\
\hline \multicolumn{3}{|l|}{$\begin{array}{l}\text { Modification } \\
\text { Of FMEA }\end{array}$} \\
\hline & Holistically - oriented FMEA & Devadasan et al., (2003) \\
\hline & $\begin{array}{l}\text { Reliability assessment of product } \\
\text { re-manufacture }\end{array}$ & Lam et al., (2001), Parkinson and Thompson (2004), \\
\hline & $\begin{array}{l}\text { Reliability assessment of lean } \\
\text { manufacturing system }\end{array}$ & Shaweney et al., (2010) \\
\hline & $\begin{array}{l}\text { Evaluating qualitative attribute of } \\
\text { business process }\end{array}$ & Zakarian et al., (2006) \\
\hline $\begin{array}{l}\text { FMEA } \\
\text { Automation }\end{array}$ & & Wirth et al., (1995), Tso et al.,(2005), Lee at al., (2010) \\
\hline \multicolumn{3}{|l|}{$\begin{array}{l}\text { Enhancement of } \\
\text { Failure } \\
\text { Assessments }\end{array}$} \\
\hline & Behaviour Modelling & $\begin{array}{l}\text { Eubanks et al.,(1996), Kmenta et al., (1997), Kmenta and } \\
\text { Ishii (1998) }\end{array}$ \\
\hline & Petri Net & Adamyan and He (2004) \\
\hline & $\begin{array}{l}\text { Framing Interactive Failure } \\
\text { evaluation }\end{array}$ & Nepal et al., (2008) \\
\hline
\end{tabular}

\section{New Research Challenges}

4.1 Enhancing the Risk Priority Number estimation Methodology

Correct evaluation of RPN is important in FMEA stages since it is the basis for resource allocation to curb the cause of service reliability problem. To overcome the shortcomings of the RPN estimation method based on Military Standard 1629A, many techniques have been proposed as shown in Table 1 . However, the basis to build various RPN estimation techniques is still based 
on 1- 10 scale of RPN ratings that seemed to have less scientific basis. Furthermore, as failure event occurrences are time dependent phenomena, the role of time as dimension to estimate the RPN should also be considered in future research. Fulfilling the gap on counting the RPN metric into more scientific basis, Sutrisno and Kwon (2010) presented risk reprioritisation approach using conditional probability. Extending their study, new opportunities in this research direction are as below:

- How to determine the RPN reprioritisation method by considering the occurrences of failure events along finite time span with uncertainty in their number and time occurrences?

- Previous RPN estimation methods are neglecting the reality that service customers in some situations are still tolerating against failure occurrences. In this case, the question for next study is on "how to incorporate the aspect of customers' tolerability in counting the risk of service failure"?

- Although the use of cost as basis to prioritize the risk seemed to be useful for practical situation, some works are still waiting ahead to develop it by incorporating input from other disciplines such as physiology and sociology. For example, "how we can quantify the cost based- risk of patient worry (fear) due to medical malpractice"?

- All service FMEA studies above are only viewing risk of failure as a treat to firm. Meanwhile, the occurrence of failure event is also creating opportunities to firm. From this perspective, embodiment of the concept on competing threat and opportunity into FMEA, and how to determine the ratings scale of opportunity priority number as proposed by Koo et al. (2008) into more scientific basis is still becoming big question to answer?

- The basic principle of previous FMEA methodology is that the attention of FMEA decision makers to curb the of service quality problems should be prioritised to the failure modes with the highest RPN. However, in daily situation; the FMEA team has to deal with multi conflicting service attributes that are often opposing one another.

- Referring to the cost oriented RPN reprioritisation methods and the use of Taguchi Loss Function to quantify deviation from customers' specification, "how can we make balance corrective improvements since spending too many resources to rectify quality problems is a gain to customer but a loss to service provider”?

\subsection{Modification of FMEA to Create Resilient Service Systems against Jay Customers}

Jay customers are kind of customers who abuse services to service providers or to customers. They should also be considered in design resilience service since their economic, social, and physiological impact cannot be neglected. Although efforts have been dedicated to modify FMEA to deal with holistic failure assessment from every company functions (Devadasan et al. 2003) and embodiment of robust design into FMEA (Mekki, 2006), it looked that previous modification overlook on the existence of jay customers. Many challenges are still remaining left on modelling the interaction between impact of internal service failure and external service failure due to customers' abuse and counting the RPN of service failure occurrences in such situation.

\subsection{Combination of FMEA and other Quality Control Tools}

In order to improve capability of FMEA, previous researchers have devoted in combining it with other quality tools. Linking attribute of customer dissatisfactions into Quality Function Deployment (QFD) can be a starting point toward better service provision. Initial research that modifies QFD to deal with customer service problems is proposed by Stauss (1993). Labridus and Schibowsky (1994) presented integration on Aggregate Analysis and QFD to analyse customer dissatisfactions. Shahin (2004) combined Kano and FMEA to customer centered service dissatisfaction assessment. As reliable service design needed to be constructed into more systematically business process, embodiment of Axiomatic Design into integration among Kano Method, FMEA, and QFD toward customer dissatisfaction-based service design seemed promising as new research direction. Furthermore, as corrective actions should also consider the competitive situation, linking the result of Kano Method, FMEA, QFD, Porter Competitive Model and Game Theory also seemed to be promising area for deeper study. Since service operations are mostly practiced in multistage operation in industry, combining cause selecting control chart with FMEA is challenging study. At last, testing the robustness of proposed corrective actions with design of experiments (DoE) upon integration among Kano Method, QFD and FMEA is also important and absent in contemporary literature.

\subsection{Application of FMEA in Service Supply Chain Framework}

As business paradigm has moved from individual enterprise centric into supply chain centric oriented, endeavours to develop FMEA within supply chain framework are growing. Sinha et al. (2004) used FMEA to access criticality of risk factors within aeroplane manufacturing supply chain. Teng and Ho (2006) discussed problems of FMEA application in collaborative manufacturing environment. Kumar et al. (2009) presented FMEA study to access risk of each steps in reverse logistics activities within pharmaceutical industry.

Referring to Seth et al. (2006a) and Seth et al. (2006b), variation in external factors among tiers will naturally cause service quality variations. As every tier involved in such business relationship has different priorities in viewing risk will make endeavour to solve collaborative risk become challenge. In addition to Vanany et al. (2009); many works are still remaining left for future studies. 
For example,

- What metrics shall be used to model the risk caused by qualitative measures such as difference in customs, language, and regulations and so on among tiers?

- How to allocate appropriate resources to curb faulty service provision occurred at certain tier?

- How to model the propagated reverse -and forward risk of service quality deficiencies?

- How to isolate the source of service quality problems in complex tiers relationship?

- What and how to share information among tiers by considering confidentiality?

- What kind of decisions support tools should be designed to facilitate tiers to choose among various risk handling techniques?

Finally, extending the study of Shahin (2010), what and how should we determine the service producer(s) and customer(s) within service supply chain framework is critical for future research.

\subsection{Application of Service FMEA to Support Transition to Product-Service System (PSS).}

Driven by the degrading revenue from pure product selling business, companies are now changing their business paradigm into incorporate product service model in their sales process (Kim et al. 2010). To improve transition from such situation, identification of critical success factors by mitigating obstacles from changing business process from pure manufacturing to PSS oriented as revealed by Uchihara et al. (2006) using FMEA is still unknown. Next, continuing the research of Lee et al. (2010b), what and how should service FMEA be used as tool to measure and manage the risk of transforming from pure manufacturing to productservice oriented companies.

\subsection{Expanding the Application of FMEA in Non Profit Service Sectors}

\subsubsection{Humanitarian and Governmental Service Sector.}

Humanitarian logistics service is a growing field (Mc Lachin et al. 2009). Schultz et al. (2009) presented the indicators to measure logistics-oriented service operation. Oloruntoba and Gray (2009) revealed that the structure, service quality attribution and entity model of tiers and players in humanitarian service operation are different from profit oriented service supply chain. Based on their propositions, some research questions to answer in this domain are:

- What and how to rank the interrelated critical risk factors in humanitarian service supply operations?

- What is the most critical service quality attributes that leads to customer's dissatisfactions?

- How to expand the concept of reliable and lean philosophy to humanitarian service operations?

Extending the lack of attention on improving reliability, innovativeness, and productivity of public service delivery, empirical researches in using FMEA to uncover the cause of lower productivity and innovation of governmental service and comparing it among countries seem to be interesting research avenue.

\subsection{Development and Application of Service FMEA in Green Service Profit Chain}

Dealing with immaturity in the structure of service supply chain and sustainability issues, researchers have proposed application of sustainability-FMEA related studies. Lindahl (2002) presented environmental FMEA (E-FMEA) model based on product design perspective. Hsu and Hu (2008) revealed key dimensions and approaches in adopting green supply chain. Hu et al. (2009) proposed the risk estimation techniques based on FMEA and AHP of electronics product manufacturing. Baltciouglu et al. (2010) proposed a framework for service supply chain. Kassinis and Soteriou (2003) showed that the environmental practices of service firms are positively affecting the customer satisfaction. The gap in previous research is performing empirical study on service reliability assessment in a green-oriented service supply chain of any business practice.

\subsection{Utilization of customer complaint data for continuous learning process}

Using report from customer complaint is invaluable toward improved service operation. Uusitalo et al. (2008) introduced a process-oriented framework in handling complaints. Lee et al. (2010a) presented computerised reliability problems with Failure Reporting, Analysis, and Corrective Actions (FRACAS) systems. By assuming the methods on mining and dealing vagueness of customers complaint are available; the next challenge to use information from such data mining result are on how to share the data, and use it for continuous improvement. Finally, referring to Hensley and Sulek (2011), how and to what extent should we incorporate customer feedbacks and their involvements in improving service reliability upon FMEA is accomplished. 


\subsection{Application of FMEA for Accessing Sustainability of Service Business}

Sustainability is contemporary issue that is driven by imbalance between growing trend of global consumption and the trend of depleted natural resources. For the survival, service firms shall identify and design service operations by referring to four dimension of sustainability namely social, economical, technical, and environmental sustainability. Initial study to deploy sustainability metrics can be found in Edgeman and Hensler (2005).

In this part, some unanswered research questions are:

- What metrics that represent above such dimensions?

- How to quantify the four sustainability metrics since customer(s) of sustainability aspect is our descendant that possibly will have different expectations from nowadays?

Using FMEA to identify the risk factors related to those sustainability metrics and integrating them into QFD to formulate the best sustainability strategy of service operation is still absent in literature.

\section{Conclusion}

Among service quality attributes, service reliability is one of the sources of customer dissatisfaction and should be managed proactively for business sustainability. The result from our initial literature survey indicated that service FMEA researches are still dominated by profit and single company orientation, and overlook on the utilisation of service FMEA in supply chain operation. Although many endeavours have been dedicated to utilise FMEA in various service sectors, driven by the challenges in modern business and the escalation of global disastrous events, many gaps are still left for future study. Certainly, this paper is not free from limitations. As this study is merely based on limited literature, we encourage future researches to extend our initial survey by using more databases and incorporate other type of references such as book chapters, dissertations, and literature that are written using languages other than English. Moreover, we also suggest that other researchers to widen discussion on the role of FMEA in enhancing six sigma-oriented service systems, focus to human error issues, application of service FMEA in virtual setting, and its role in creating value within collaborative business framework.

\section{Acknowledgements}

The first author would thanks to Dr. Elizabeth Cudney and anonymous referees for their comments which improve the presentation of this study. Also, the first author's thanks to Prof. Hyuck Moo Kwon for support during the manuscripts preparation and Prof. Jean Couillard suggestions during manuscript preparation. Financial Support from Ministry of Education, Republic of Indonesia and Pukyong National University to accomplish this study is gratefully acknowledged.

\section{References}

Atike, F., S.Tiras,I.Dunder, A.Bahtiyar, O.A. Uzun, Demiran, O., 2010. A New scale for evaluating the risks for in -hospital falls of newborn infants: a fmea study, International Journal of Pediatrics, vol.2010, pp.1-8.

Albuquerque, A.R., J.B.Klierwer, I.P. de Arruda Campos, C.Studzinki, Kliwer, M., 2009. Risk evaluation supported by annotated paraconsistent logic: a study of a vehicle manufacturer. Journal of Achievement in Materials and Manufacturing, vol.32, no.4, pp. 81-91.

Arvanitoyannis, I., Palaikortas, C., Panagionaki, P., 2009. A comparative presentation of the implementation of iso 22000 versus haccp and fmea in a small size greek factory producing smoked trout: a case study, Critical Reviews in Food Science and Technology, Vol.49, no.2, pp. 176-201.

Aksezer, Cagla., 2010. Reliability evaluation of healthcare services by assessing the technical efficiency, The Service Industries Journal, iFirst Article, pp.1-11.

Almanai, B., R. Greenough, Kay, J., 2008. A decision support tool based on qfd and fmea for the selection of automation technology, Robotics and Computer Integrated Manufacturing, Vol.24, No.4, pp. 501-507.

Al-Mishari, S.T., and Sulaiman, S., 2008. Integrating six sigma with other reliability improvement methods in equipment reliability and maintenance applications, Journal of Quality in Maintenance Engineering, vol.14, no.1, pp. 59-70

Ahsen, Annete von 2008. Cost-oriented fmea. International Journal of Quality and Reliability Management, Vol. 25, no.5, pp. 466-476.

Al Mashari, M, M.Zairi, and Ginn, D. 2005. Key enablers for the implementation of QFD: a critical Analysis. Industrial Management and Data Systems, Vol. 105, no.59, pp. 1245-1260.

Adamyan, A., and He, D., 2004. System failure analysis through counters of petri net models, Quality and Reliability Engineering International, vol.20, no.4, 317-335.

Bowman, K., Huffman, D, Gross, G.. 2010. Fmea at the residential care facility. Proceedings of Annual Reliability and Maintenability Symposium, San Jose, pp. 1-5. 
Buksa, T., D.Paulevic, Sokovic. M., 2010. Shipbuilding pipeline production quality improvement, Journal of Achievement in Material and Manufacturing, vol.32, no.1, pp. 81-91.

Baltacioglu, T., Ada Erhan, D. Melike, Y Oznur Y, and Kaplan, Y.C., 2009. A new framework for service supply chains, The Service Industries Journal, Vol.27, no.2, 105-124.

Bhamare, S.B., O.P. Yadav, and Rathore, A., 2007. Evolution of reliability engineering discipline over the last six decades: a comprehensive review, International Journal of Reliability and Safety, vol.1, no.4, 377-410.

Bertolini, M., M. Braglia, and Carmignani., G. 2006. An - fmea -based approach to process analysis. International Journal of Process Management and Benchmarking Vol.1, no.2, pp. 127-145.

Bertolini, M, M. Bevilacqua, Mason, G. 2006. Reliability design of industrial plant using petri nets, Journal of Quality in Maintenance Engineering, Vol.12, no.4, pp.397-411.

Bosch,Veronica Gonzales and Enriques, F. 2005. Tqm and qfd: exploiting a customer complaint management system. International Journal of Quality and Reliability Management, vol.22, no.1, pp. 30-37.

Braglia, Marcello 2004. Mfmea: multi attribute fmea, International Journal of Quality and Reliability Management, Vol. 17, no.9, pp. 1017-1033.

Bariani, P.F., Berli, G.A., and Lucchetta, G., 2004. A combined dfma and triz approach to the simplification of product design structure, Journal of Engineering Manufacture, vol.218,no.8,pp:1023-1027.

Bullinger, H.J., K.L. Fahnrich, and Meiren, T, 2003. Service engineering- methodical development of new service products, International Journal of Production Economics, vol.85, no.3, pp. 275-287.

Bahmed, Lydia., A. Boukhalfa, Mebarek, J. 2006. Eco-conception in the industrial firms: methodological propulsion, Management of Environmental Quality: An International Journal, Vol.16,No.5, 530-547.

Braglia, M., M. Frosolini, Montanari,R., 2003. Fuzzy criticallity assessment model for fmea, International Journal of Quality and Reliability Management, Vol.20, no.4, pp.503-524.

Byrne, G, and Sheahan, C., 2007. Integrated risk minimization methodology for high volume manufacturing. Journal of Manufacturing Technology Management, Vol.18, no.5, pp. 538-548.

Braglia, M., A.Grassi, Montanari, R., 2005. Multi-attribute classification method for spare parts inventory management, Journal of Quality in Maintenance Engineering, vol.10,no.1, pp.55-65.

Berkley, Blair J.,1998. Application of fmea to nightclub security. Journal of Hospitality and Tourism, Vol.21, no.3, pp. 93-105.

Boyd, M.A., A. Abou-Khalil, T.A. Montgomery, Gebrael, M., 1998. Development of automated computer-aided diagnostic system using FMECA-based knowledge capture methods, Proceedings of Annual Reliability and Maintenability Symposium,

Ben Daya, M., Raouf, A. 1996. A revised fmea, International Journal of Quality and Reliability Management, Vol.13, no.1, pp.4347.

Bouti, Abdelkader., Kadi, D.A., 1994. A state of the art review of fmea/fmeca. Int. Journal of Reliability, Quality, and Safety Engineering Vol 1, No.4, pp. 515 - 543.

Chuang, Pao-Tiao 2010. Incorporating disservice analysis to enhance perceived service quality. Industrial Management and Data Systems, vol.110, no.3, pp. 1-22.

Chang, K.H., and Cheng, C.H., 2011. Evaluating the risk of failure using the fuzzy owa and dematel method, Journal of Intelligent Manufacturing, vol.22, no.2, pp.113-129.

Chen, Z., K.M. Feng, G.S. Zhang, T.Yuan, Pan, C.H., 2008. Preliminary safety research for ch hcsb tbm based on fmea method. Fusion Engineering and Design, Vol.83, no.5-6, pp. 743-746.

Casseroti, Vittorio and Spada, C., 2009. A systematic approach to achieve operational excellence in hotel services, International Journal of Quality and Service Sciences, vol.22, no. 1, pp. 30-37.

Chen, L.H., and Ko, W.C., 2009. Fuzzy linear programming model for the new product design using qfd and fmea, Applied Mathematical Modelling, vol, 33, no.2, pp. 633-647.

Carmignani, G., 2009. An integrated structural framework to cost -based fmea: The priority - cost fmea. Reliability Engineering and System Safety, vol. 94, no.4, pp.861-871.

Chang, D-S.,and Sun, Paul, K.L., 2009. Applying dea to enhance assessment capability of fmea, International Journal of Quality and Reliability, vol.26, no.6, 629-643.

Chin, K.S., Y.M. Wang, G.K.K.Poon, and Yang, J.B. 2009. Fmea using a group based evidential reasoning approach. Computers \& Operations Research, Vol.36, no.6, pp. 1768-1779.

Chuang, Pao-Tiao 2007. Combining service blueprint and fmea for service design. The Service Industries Journal, vol. 27, no.2, pp. 91-104.

Chiozza, M.L., and Pozzali, C., 2009. Fmea: a model for reducing medical errors. Clinica Chimia Acta, vol.404. no.1, pp. 75-78.

Chase, R. B., and Apte, U.M., 2007. A history of research in service operations: what is the big idea?. Journal of Operations Management, Vol.25, pp. 375-386.

Casado-Diaz, Anna B. and Nicolau -Gonzalez, Juan L,. 2009. Explaining consumer behavior in double deviations: the Banking Service. The Service Industry Journal, vol. 29, no. 12, pp. 1659 - 1668.

Chen, J.K , 2007. Utility priority number for fmea, Journal of Failure Analysis and Prevention, Vol.7, No.5, pp.321-328. 
Chao, L., and Ishii, K.2003. Design error proofing: development of automated error-proofing information systems, Proceedings of the 2003 DETC, Chicago, Illinois.

Dai, Y., Y.Xue, Z.Han, Zhang, W., 2008. Risk occurrence assessment of the background conformity conditions of inspection and quarrantine Based on fmea, International Journal of Business and Management, vol.3, no.10, 37-44.

Deng, W.J., E.Qi, Liu, Z., 2002. Continuous improvement through integration of quality tools, Asian Journal on Quality, Vol.2, no.2, pp.137-158.

Davidson, G.., Labib, A.W. 2003. Learning from failures: design improvement using multiple criteria decision making process. Journal of Aerospace Engineering, Proceedings of the Institution of Mechanical Engineers Part G ,(217), pp. 207-216.

Dilibabu, R., and Krisnaiah, K. 2006. Application of fmea to software code reviews-a case study, Software Quality Professional, vol.8, no.2, pp.30-41.

Dhillon, B.S., 2003. Methods for performing human reliability and error analysis in health care. International Journal of Health Care Quality Assurance, Vol16, no. 6, pp. 306-317.

Devadasan, S.R., S.Muthu, R.N. Samson, and Sankaran, R.A., 2003. Design of total fmea programme. International Journal of Quality and Reliability Management, vol.20. no.5, pp:551-568.

Estorillo, C., and Posso, R.K., 2010. The Reduction of irregularities in the use of "process fmea”. International Journal of Quality and Reliability Management, vol.27, no.6, pp.721-733.

Edgeman, R.L, and Hensler,, Douglas A., 2005. Qfd and the best paradigm: deploying sustainable solutions. World Review of Science, Technology, and Sustainable Development, Vol.2, no.1, pp. 49-59.

El-Harram, M.A., and Horner, M.W., 2002. Practical application of rcm to local authority housing: a pilot study, Journal of Quality in Maintenance Engineering, Vol.8, no.2, pp.135-143.

Eubank, C.F., S.Kmenta, Ishii, K.,1996. System behaviour modeling as basis for advanced fmea. Proceedings of the 1996, ASME DETC, Irvine, California.

Eubank, C.F., S.Kmenta, Ishii, K.1997. Advanced fmea using behavior modeling. Proceedings of the 1997, ASME DETC, Sacramento, California.

Foster, S.T., Junior., 2008. Toward an understanding of supply chain quality management, Journal of Operations Management, vol.26, no.4, pp. 461-167.

Fowdar, R.R. Ramsaran., 2008. The Relative importance of service dimensions in heathcare setting. International Journal of Heath Care Quality Assurance, vol. 21, no.1, pp. 104-124.

Freiesleben, J., 2008. A proposal for economic quality loss function. International Journal of Production Economics, Vol.113, no. 2, pp. 1012-1024.

Gecky, Peter, Noriaki Izumi, and Hasida, K. 2010. Service science, quo vadis? International Journal of Service Science, Management, Engineering, and Technology, vol.1, no. 1, pp. 1-16.

Giorgio, I.De, C.F. Christie, L. Cingria, B. Caredda, V. Meyer, R.E.Pfister, Bonnabry, P., 2010. Risk and pharmacoeconomic analysis of the injectable medical process in the pediatric and neonatal intensive care unit, International Journal of Quality in Healthcare, vol.22, no.3, 170-178.

Geum, Youngjung., J.Shin, and Park, Y., 2010. FMEA-based portfolio to service productivity improvement, The Service Industries Journal, iFirst, 1-23.

Gwiazda, A., 2007. Multi criteria analysis technique in a process of Quality Management, Journal of Achievement in Material and Manufacturing, vol.25, no.1, pp.75-78.

Ginn, P.M., D.V. Jones, H.Rahnejat, Zairi, M. 1998. The “qfd/fmea interface”. European Journal of Innovation Management, vol.1, no.1, pp. 7-20.

Hensley, R.L., Utley, J.S., 2011. Using reliability tools in service operations, International Journal of Quality and Reliability Management, Vol.28, no.5, 587-598.

Hassan, A.,S.Ali, J.Y.Dantan, and Martin, P. 2010. Conceptual planning - an improvement approach Using qfd, fmea, and abc, Robotics and Computer Integrated Manufacturing, Vol.26, no.4, pp.292-401.

Hsu, C.W., Hu, A.H.2008. Green supply chain management in electronics industry. International Journal of Environmental Science and Technology, Vol.5(2), pp. 205-216.

Hu, A.H., C-W Hsu, T-C Kuo, and Wu, W-Cheng.2009. Risk evaluation of green components to hazardous substance using fmea and fahp. Expert Systems with Applications, Vol.36, pp. 7142-7147.

He, Zhen, E.Qi, and Liu Z. 2002. Continuous improvement through integration of quality tools, Asian Journal on Quality, Vol,3, no. $2,38-45$

Harris, L.C., Reynold, K.L., 2004. "Jaycustomer behavior”: an exploration of types and motives in the hospitality industry. Journal of Service Marketing, vol. 18, no.5, pp. 339 - 357.

Hashim, M., 1984. Reliability concepts applied to service industries, International Journal of Quality and Reliability Management, Vol.1, no.1, pp.39-50.

Inoue, H. and Yamada, S., 2010. Fmea in pharmaceutical research, International Journal of Quality and Service Science, vol.2, no.3, pp. 369-382. 
Ilangkumar, M.P., Thamizhselvan, M.P. 2010. Integrated hazard and operability study using fuzzy linguistics approach using fuzzy linguistics approach in petrochemicals industry. International Journal of Quality and Reliability Management, vol. 27, no.5, pp. 541-557.

Jennifer, Jeong, Sylvia Hyland, Catherine M. Burns, Momtana, K., 2007. Challenges with applying fmea to the process for reading labels on injectable drug containers. Proceedings on Annual Meetings of Human Factors and Ergonomics Society, pp: 735-739.

Jegadeshan,C., V.P. Arunachalam, S.R. Devadasan, Srinivasan, P.S.S., 2007. Design and development of modified service fmea model. International Journal of Services and Operations Management, Vol.3, No.3, pp.111-126.

Johston, R., 2005. Service operation management: from the roots up, International Journal of Operations and Production Management, Vol.25, no.2, pp:1298 - 1308.

Kumar, Sameer, Erin Dieveney, Aaron Dieveney, 2009. Reverse logistic process control measures for the pharmaceutical industry supply chain, International Journal of Productivity and Performance Management, vol.58, no.2, pp. 188-204.

Korayem, M.H., and Iravani, A. 2008. Improvement of 3rp and 6r mechanical robots Reliability and Quality Applying FMEA and QFD Approaches. Robotics and Computer Integrated Manufacturing, vol.24, no.3, pp.472-487.

Kuo, Y.F., S.T. Yen, Chen, L.H. 2009. Online auction service failures in taiwan: typologies and recovery strategies, Electronics Commerce Research and Application, doi:10.1016/j.elerap 2009.09.003.

Koo, L.C, H.Koo, Lewis. L. 2008. A pragmatic and holistic approach to strategic formulation through adopting balance score card, swot analysis, and blue ocean strategy: - a case study of consumer product manufacturer in china, International Journal of Managerial and Financial Accounting, Vol.1, no. 2, pp. 127-146.

Karuppuswamy, P., G.Sundararaj, S.R.Devadasan, D.Elangovan,and Savadamuthu, L., 2006. Failure reduction in manufacturing system through the risk management approach and the development of a reactive maintenance model. International Journal of Risk Assessment and Management, vol.6, no.4/5//6, pp.545-564.

Kmenta, S., Ishii, K. 2004. Scenario-based fmea using expected cost. Journal of Mechanical Design. Vol.126, No.6, pp.10271035.

Kwon, S.K., K.K. Lee, Park, Y.H, 2007. A study on methodology of integrating lean design for six sigma and advanced product quality planning in iso/ts 16949, Asian Journal on Quality, Vol.8, no.3, 173-187.

Kassinis, G.L., and Soteriou, A.C., 2003. Greening the service profit chain: The impact of environmental management practices, Production and Operations Management, Vol.12, no.3, pp.386-403.

Kmenta, S. and Ishii, K.1998. Advanced fmea using meta behaviour modeling for Concurrent Design of Product and Control, Proceedings of DETC, Atlanta, Georgia.

Lee, J.H., S.I. Chan, Jang, J.S. 2010a. Process-oriented development of failure reporting, analysis, and corrective action system. International Journal of Quality, Statistics, and Reliability, Vol.2010, pp. 1-8.

Lee, A.H.I., C.S.Wei, and Y.C. Lee, 2010b. An Approach for modeling the risk transformation process, International Journal of Industrial Engineering: Theory, Application, and Practice, vol.17, no.1, pp.1-11.

Leung, P., J.Abell, K.Ishii, and Benson, J., 2005. Global fmea: A planning tool for global product development. Proceedings of ASME Design Engineering Technical Conference, Long Beach, California.

Linton,J.D., 2003. Facing the challenge of service automation: An enabler for the e-commerce \& productivity gain in the traditional service, IEEE Transaction on Engineering, Vol.50, No.4, pp. 478-484.

Lam, A., M.Sheerwood, and Shu, L.M, 2001, FMEA-based design for remanufacture using automotive remanufacture data, Proceedings of Society of Automotive Engineers Congress, Detroit,

Lindhal, M., 1999. E-FMEA: a new promising tool for efficient design for environments. Proceedings of First International Symposium on Environmentally Conscious Design and Inverse Manufacturing, Tokyo, pp. 734-739.

Layzell, J., Ledbetter, Stephen., 1998. FMEA applied to cladding systems- reducing the risk of failure, Building Research and Information, Vol.26, no.6, 351-357.

Lapidus, R.S., and Schibrowsky, J.A., 1994. Aggregate complaint analysis: A procedure for developing customer service satisfaction. Journal of Service Marketing, Vol.8, No.4, pp.50-60.

Mummolo, G., R.Pilolli, D. Pugliese, .Ranieri, L. 2010. FMECA analysis of healthcare services: the evaluation of the efficiency of a hospital department. Proceedings of the International Workshop on Applied Modeling \& Simulation, May 5-7, Buzios, Rio de Janeiro.

Mc Lahin, R., P.D. Larsson, and Khan, S. 2009. Non-profit supply chains in interrupted environments: the case of a faith-based humanitarian relief organisations. Management Research News. Vol.32, no. 11, pp. 1050-1064.

Mekki, K.S., 2006. Robust design fmea in designing for six sigma, International Journal of Product Development, vol.3, no.3/4, 292-304.

Menor, Larry J., Mohan V.Tatikonda, Sampson, S.E., 2002. New services development: areas for exploration and exploitation. Journal of Operations Management, vol. 20, no.2, pp. 135-157.

Ngai, E.W.T., L.Xiu, Chan, D.C.K. 2009. Application of data mining techniques in customer relationship management : a literature review and classification, Expert System and Application, vol 36, pp:2592-2602. 
Narayangounder, S., Gurusami, K. 2009. A new approach for prioritizing of failure modes in design fmea using Anova. Proceedings of World Academy of Science, Engineering, and Technology, vol. 49, pp. 524-531.

Nepal, B.P., O.P. Yadav, L.Monplaisir, and Murat, A., 2008. A framework for capturing and analysing the failures due to system/ components interactions, Quality and Reliability Engineering International, vol.24, no.3, pp.265-287.

Nord, J.H., Nord, G.D., 1995. MIS research: journal status and analysis, Information and Management, vol.vol.29, pp. 29-42.

Ostrom, A.l., M.J. Bitner, S.W. Brown, K.A. Burkhad, M.Goul, V S. Daniels, H. Demirkan, and Rabinovich, E. 2010. Moving forward and making a difference: research priorities for the science of service. Journal of Service Reseach, Vol.13, no. 4, pp. 436.

Ozilgen, S., 2010. Application of fmea model to food service systems operated by chiefs in practice and by chefs from culinary school in turkey. Journal of Consumer Protection and Food Safety, Vol.5, No.3-4, pp.333-343.

Oolkalkar, A.D., Anil G.Joshi, .Oolkar, D.S., 2009. Quality improvement In haemodialysis process using fmea. International Journal of Quality and Reliability Management, vol.26, no.8, pp. 817-830.

Oloruntoba, R., and Gray, R., 2009. Customer service in emergency relief chains. International Journal of Physical Distributions and Logistics Management, Vol.39, No.6, pp. 486-505.

Pilay, A. and Wang, J., 2003. Modified FMEA using approximate reasoning, Reliability Engineering and System Safety, Vol.79, no.1, pp: 69-85.

Parkinson, H.J., and Thompson, G., 2004. Systematic approach to the planning and execution of product remanufacture, Journal of Process Mechanical Engineering, vol.11, no.4, 348-364.

Pujadas, W., Chen, F.F., 1996. A reliability centred maintenance strategy for a discrete part manufacturing facility, Computer and Industrial Engineering, Vol.31, no.1, 241-244.

Rotondaro, R.G., Oliviera, C.L., 2001. Using fmea to improve service quality service operation management, Proceeding of the Twelveth Annual Conference of the Production \& Operations Management Society, Orlando, Florida.

Redman, T., B. Mathews, Wilkinson, A., Ed. Snape, 1995. Quality management in services: is the public sector keeping pace? International Journal of Public Sector Management, vol.8, no.7, pp.21-34.

Schulz, S.F., Heigh Ian. H., 2009. Logistics performance management in action within a Humanitarian Organisation. Management Research News, Vol.32, no.11, pp. 1038-1049.

Sharma, R.K., Sharma, P., 2010. System behavior modeling and maintenance decision making using rca, fmea, and fm. Journal of Quality in Maintenance Engineering, Vol.16, No. 1, pp. 64-88.

Sawhney, R., K.Subraman, C. Sontagg, P.R.V. Rao, Capitzi, C. 2010. A modified fmea approach to enhance reliability of lean systems. International Journal of Quality and Reliability Management, Vol 27, no. 7, pp. 832-855.

Shahin, A., 2010. SSCM: service supply chain management, International Journal of Logistics Systems and Management, Vol.6, no.1, 60-75.

Sachdeva, A., D.Kumar, Kumar, P., 2009. Multi-factor failure mode criticallity analysis using topsis, International journal of Industrial Engineering , Azad Islamic University, Vol.5, no.8, 1-9.

Sinthavalai, R., Memongkol, N., 2008. A case of fmea implementation in the educational sector and integration with customer relationship management and qfd concepts. Proceedings of IEMC Europe Engineering Management Conference, Estoril, pp. $1-5$.

Segismundao, A., Miguel, P.A.C., 2008. Fmea in the context of risk management in new product development. A case study in an automotive company, International Journal of Quality and Reliability Management, vol.25, no.9, 899-912.

Sharma, R.K., D. Kumar, Kumar, P., 2007. Behaviour analysis and resource optimization for an industrial system. Int. Journal of Industrial and System Engineering, Vol., no.4, pp. 413-443.

Senol, Sansli., 2007. Poisson approach to determine the occurrence degree in failure mode and effect reliability analysis, The Quality Management Journal, vol.14, no.2, pp. 29-40.

Shahin, Arash., 2004. Integration of fmea and the Kano model: an exploratory examination. Int. Journal of Quality and Reliability Management, vol. 21, no.7,pp. 731 - 746.

Sinha, Pankaj Raj, Larry E. Whitmann, Malzan, D. 2004. Methodology to mitigate supplier risk in an aerospace Supply Chain. Supply Chain Management: An International Journal, Vol. 9, no.2,pp. 154-168.

Seth, Nitin, S.G.Deskmukh, Vrat, P., 2006a. A framework for measurement of service quality in supply chain.

Supply Chain Management: An International Journal, Vol. 11, no. 1,pp. 82-94

Seth, Nitin, S.G. Deskmuh, Vrat. P., 2006b. A conceptual model for quality service in the supply chain. International Journal of Physical Distribution \& Logistics Management, Vol.36, no.7, pp. 547-575.

Sampson, S.E.,2000, Customer- supplier duality and bi-directionality supply chains in service organizations, International Journal of Service Industry Management, vol.11, no.4, 348-364.

Stauss, Brend.,1993. Service problem deployment. transformation of problem information into problem prevention activities. International Journal of Service Industries Management, Vol.4, no.2, pp. 41-62.

Tanik, Murat., 2010. Improving "order handling "process by using qfd \& fmea methodologies: A case study. International Journal of Quality and Reliability Management, Vol.27, no.4, pp. 404-423. 
Tso, K.S., A.T.Tai, S.N.Chau, and Alkalai, L., 2005. On automating fmea and enhancing its integrity. Proceedings. Of $11^{\text {th }}$ International Symposium on Dependability Computing, Los Angeles.

Teng, G., S.M Ho, D.Shumar, Liu, P.C., 2006. Implementing fmea in a collaborative supply chain framework. International Journal of Quality and Reliability Management, vol.23, no.2, pp. 179-196.

Teng, G.S., Ho, S.Y., 1996. Fmea: an integrated approach for product design and process control. International Journal of Quality and Reliability Management, vol.13, no.5, pp. 8-26.

Qiang, Rui., 2009. Research on sales quality system improvement based on fmea. International Conference on Service System \& Service Management, Xiamen, China, pp: 905-909.

Torney, M., K.Kunizky, Hermann, C.. 2009. Service development and implementation: A review of the state of the art. Proceedings of the $1^{\text {st }}$ CRIP Industrial Product and Service System, Cranfield University, United Kingdom, p.224.

Teng. G.S., Michael Ho, Debra Shumar, Liu, P.C., 2006. Implementing fmea in a collaborative supply chain environment, International Journal of Quality and Reliability Management, vol.23,no.2, pp. 179-186.

Thivel, P.X., Y.Butel, and Delpech, F., 2008. Risk analysis of a biomass combustion process using mosar and fmea methods, Journal of Hazardous Materials, Vol.151, no.1, pp. 221-231.

Uusitalo, Kari., H. Hakala, and Kautomen., 2008. Customer complaints as source of customer focused process improvement.: A conceptual case study. International Journal of Business Science and Applied Management, Vol.3, no.1, pp.1-13.

Van Leeuwen, J.F., M. J. Nauta, D.de Kaste, Y.M.C. F. Odekerken- Rombouts, M.T. Oldenhof, M.J. Vredenbert, and Barends, D.M., 2009. Risk anaysis by fmea as an element of analytical validation, Journal of Pharmaceutical and Biomedical Analysis, vol. 50, no. 5, pp.1085-1087.

Varzakas, T.H., Arvanitoyannis, I., 2007. Application of fmea, cause and effect analysis, and pareto diagram in conjunction with haccp to a corn manufacturing plant, Critical Review in Food Science and Nutrition, vol.47, no.4, pp. 363-387.

Vanany, I., S. Zaelani, and Pujawan, N., 2009. Supply chain risk management: literature review and future research. International Journal of Information Systems and Supply Chain Management, Vol.2, no.1, pp.16-33.

Wang, F,K, and Chen, K.S., 2010, Applying lean six sigma and triz methodology in banking services. TQM and Business Excellence, Vol.21, no.3, pp.301-315.

Wolfram, A., D. Tavor, S. Mark, M. Schermann, , and Kremer. H., 2010. $S^{3}$-sustainability and service science: novel perspective and challenge. Service Science, Vol.2, No.4, pp. 216-223.

Wang, Ying-Ming, Kwai - Sang Chin, Gary Ka Wai Poon, Yang, J.B., 2009. Risk evaluation in fmea using fuzzy weighted geometric mean. Expert System with Applications, vol.36, no.2, pp.1195-1207.

Werner, S., Compart, W.F., 2007. Assessing safety in distillation column using dynamic simulation and fmea, Journal of Applied Sciences, vol.7, no.5, 2033-2039.

Wong, C.L., Tsang, A.H.C., and Chung, T.S., 2006. A methodology for availability assessment of tunnel design, International Journal of Quality and Reliability Management, vol.23, no.1, 60-80.

$\mathrm{Xu}, \mathrm{X}$., Wang Z., 2009. State of the art: business service and its impact on manufacturing, Journal of Intelligent Manufacturing, DOI:10.1007/s.10845-009-0325-3.

Yeh, R.H., and Hsieh, M.H., 2007. Fuzzy assessment of fmea for a sewage plant, Journal of Chinese Institute of Industrial Engineering, Vol.24, no.6, 505-512.

Yadav, O.P., and Sing, N., 2008. Perspectives and challenges for product reliability assurance in the product development process, International. Journal of Product Development, Vol.5, no.1-2,pp. 4-16.

Yang, C.C., W.T. Lin, M.Y.Lin, and Huang, J.T., 2006. A study on applying fmea to improving erp introduction. an example of semiconductor related industries in Taiwan, International Journal of Quality and Reliability Management, vol.23, no.3, pp.298322.

Yang, Zhilin, R.T.Peterson, and Cai, S., 2003. Service quality dimension of internet retailing: an exploratory analysis. Journal of Service Marketing, vol. 17, no.7, pp.685-700.

Zhang, Jie., and Zhu, Q., 2009. Fmea based potential risk analysis of lower cost region sourcing. In Proceedings of IEEE International Conference on Service Operation, Logistics, and Informatics, Shanghai.

Zakarian, A., P.Wickett, and Siradegyan, Y., 2006. Quantitative model for evaluating the quality of an automotive business process, International Journal of Production Research, vol.44, no.1, pp. 1005-1074.

Zafiropoulos, E.P., and Dialynas, E.N., 2000. Reliability prediction and fmeca of electronic devices using fuzzy logic, International Journal of Quality and Reliability Management, vol.22, no.2, 183-200.

\section{Biographical Notes}

Agung Sutrisno obtained his B.Eng and M.Eng in Metallurgical and Material Engineering and Manufacturing Engineering from University of Indonesia in 1999 and 2001. He is a lecturer at Department of Mechanical Engineering, Sam Ratulangi University, Manado, Indonesia. His research interests are quality, maintenance, operation and service engineering. 
Tzong-Ru (Jiun-Shen) Lee is a Professor of Marketing department, Chief of Media Relations Division, former Chairman of Marketing department and formal Chairman of Institute of Electronic Commerce and former Chairman of Center for Electronic Commerce and Knowledge Economics Research in National Chung Hsing University in Taiwan. He is a 2006 Fulbright visiting professor in USA and a joint author of four books. His researches mainly focus on SCM, CRM, Marketing, EC, Risk Management, and Business Ethics. Also, he is the editor of IJECRM and the associate editor of IJLEG.

Received January 2011

Accepted May 2011

Final acceptance in revised form May 2011 